\title{
Posttraumatic stress disorder: a serious post-earthquake complication
}

\author{
Transtorno do estresse pós-traumático: complicação séria pós-terremoto
}

\author{
Mudassir Farooqui, ${ }^{1}$ Syed A. Quadri, ${ }^{2}$ Sajid S. Suriya, ${ }^{2}$ Muhammad Adnan Khan, ${ }^{3}$ Muhammad Ovais, ${ }^{4}$ Zohaib Sohail, ${ }^{5}$ \\ Samra Shoaib, ${ }^{3}$ Hassaan Tohid, ${ }^{3,6}$ Muhammad Hassan ${ }^{7}$
}

\begin{abstract}
Objectives: Earthquakes are unpredictable and devastating natural disasters. They can cause massive destruction and loss of life and survivors may suffer psychological symptoms of severe intensity. Our goal in this article is to review studies published in the last 20 years to compile what is known about posttraumatic stress disorder (PTSD) occurring after earthquakes. The review also describes other psychiatric complications that can be associated with earthquakes, to provide readers with better overall understanding, and discusses several sociodemographic factors that can be associated with post-earthquake PTSD

Method: A search for literature was conducted on major databases such as MEDLINE, PubMed, EMBASE, and PsycINFO and in neurology and psychiatry journals, and many other medical journals. Terms used for electronic searches included, but were not limited to, posttraumatic stress disorder (PTSD), posttraumatic symptoms, anxiety, depression, major depressive disorder, earthquake, and natural disaster. The relevant information was then utilized to determine the relationships between earthquakes and posttraumatic stress symptoms.

Results: It was found that PTSD is the most commonly occurring mental health condition among earthquake survivors. Major depressive disorder, generalized anxiety disorder, obsessive compulsive disorder, social phobia, and specific phobias were also listed.

Conclusion: The PTSD prevalence rate varied widely. It was dependent on multiple risk factors in target populations and also on the interval of time that had elapsed between the exposure to the deadly incident and measurement. Females seemed to be the most widely-affected group, while elderly people and young children exhibit considerable psychosocial impact.

Keywords: Earthquake, posttraumatic stress disorder, mental health, major depressive disorder, anxiety, prevalence, risk factors.
\end{abstract}

\begin{abstract}
Resumo
Objetivos: Terremotos são desastres naturais imprevisíveis e devastadores. Eles podem causar destruição em massa e morte, e os sobreviventes podem apresentar sintomas psicológicos severos. O objetivo deste estudo foi revisar estudos publicados nos últimos 20 anos pra compilar o conhecimento disponível acerca da ocorrência de transtorno do estresse pós-traumático (TEPT) após terremotos. A revisão também descreve outras complicações psiquiátricas que podem estar associadas a terremotos, oferecendo aos leitores um melhor entendimento geral sobre o assunto, e discute vários fatores sociodemográficos que podem estar associados com TEPT pós-terremoto.
\end{abstract}

Métodos: Foi realizada uma busca de literatura nas principais bases de dados, como MEDLINE, PubMed, EMBASE e PsycINFO, e também em revistas de neurologia e psiquiatria, e vários outros periódicos médicos. Os termos usados nas buscas eletrônicas incluíram, mas não se limitaram a, posttraumatic stress disorder (PTSD), posttraumatic symptoms, anxiety, depression, major depressive disorder, earthquake e natural disaster. As informações relevantes foram então utilizadas para determinar as relações entre terremotos e sintomas de estresse pós-traumático.

Resultados: A revisão revelou que o TEPT é a condição de saúde mental mais comum em sobreviventes de terremoto. Depressão maior, transtorno de ansiedade generalizada, transtorno obsessivo-compulsivo, fobia social e fobias específicas foram outras condições encontrados.

Conclusão: A prevalência de TEPT variou bastante. O transtorno foi dependente de múltiplos fatores de risco em populações-alvo e também do intervalo de tempo decorrido entre a exposição ao incidente fatal e a avaliação. As mulheres pareceram ser o grupo mais amplamente afetado, ao passo que idosos e crianças demonstração considerável impacto psicossocial.

Descritores: Terremoto, transtorno do estresse pós-traumático, saúde mental, depressão maior, ansiedade, prevalência, fatores de risco.

\footnotetext{
${ }^{1}$ University of Oklahoma Health Sciences Center, Oklahoma City, OK, USA. ${ }^{2}$ California Institute of Neurosciences (CIN), Thousand Oaks, CA, USA. ${ }^{3}$ California Institute of Behavioral Neurosciences \& Psychology, Fairfield, CA, USA. ${ }^{4}$ Saint Louis University, Department of Biostatics, St. Louis, MO, USA. ${ }^{5}$ Psychiatry and Behavioral Sciences, University of Kansas School of Medicine, Wichita, KS, USA. ${ }^{6}$ Center for Mind \& Brain, Department of Neurology, University of California, Davis (UC Davis), Davis, CA, USA. ${ }^{7}$ Dow University of health Sciences, Karachi, Pakistan.

Submitted Apr 28 2016, accepted for publication Apr 122017.

Suggested citation: Farooqui M, Quadri SA, Suriya SS, Khan MA, Ovais M, Sohail Z, et al. Posttraumatic stress disorder: a serious post-earthquake complication. Trends Psychiatry Psychother. 2017;39(2):135-143. http://dx.doi.org/10.1590/2237-6089-2016-0029
} 


\section{Introduction}

Earthquakes are considered one of the most lifethreatening, devastating, and uncontrollable of the many different types of natural disaster. An 'earthquake' is defined as persistent shaking of the surface of the earth. This shaking is measured on the 10-base Richter magnitude scale, which is determined from the logarithm of the amplitude of waves recorded by a seismometer. According to the United States Geological Survey's (USGS) National Earthquake Information Center (NEIC), it has been estimated that half a million earthquakes occur worldwide every year, but the majority of them go undetected because they strike in remote areas or are of very small magnitude and so undetectable. ${ }^{1}$ Depending on the magnitude of the earthquake, the aftermath can be disastrous and they sometimes cause homelessness, loss of loved ones, and significant mental health issues. ${ }^{2}$ Earthquakes can also cause significant destruction, massive land disruption, and major population displacement. Historically, the epicenters of earthquakes that cause the greatest loss of life have been in heavily populated areas. In 1556, an earthquake in Shaanxi province, China, took the lives of more than 830,000 people. Some massive and deadly earthquakes in recorded history include the following: 1988 in Armenia, 1999 in Turkey (Marmara), 2004 in Indonesia (Bali), 2005 in Pakistan (Northern Areas), 2008 in China (Wenchuan), and 2010 in Haiti. The most recent high magnitude earthquakes struck Japan in 2011 and Nepal in 2015. However, catastrophes have even resulted from low magnitude quakes that hit densely-populated areas, resulting in large-scale disasters, such as those recently seen in southern Taiwan and Ecuador in 2016.

Due to the high frequency of this type of natural calamity and the great suffering that ensues; many efforts have been made in the last few decades to analyze post-disaster effects in terms of mortality, morbidity, physical disability, psychological trauma, and post-disaster psychological and social adjustments. Large numbers of studies have evaluated the extent of psychological trauma and the severity of psychiatric symptoms after earthquakes and their associated risk factors amongst the survivor groups. ${ }^{2-11}$ It was recently found that the severity of psychological symptoms and modified behavior after natural disasters are affected by various factors including age, gender, marital status, loss of loved ones, proximity to the epicenter, personal health condition, and personal injuries; but these factors are superimposed on lack of social, economic, public health, and emergency medical support. ${ }^{12}$ It has also been detected that early recognition and intervention do not only help with understanding psychological symptoms, they can also reduce incidence. ${ }^{3}$ Other important factors that influence the outcomes of this type of disaster are availability of resources, good infrastructure, and better social support systems, which are all more widely available in developed countries than in developing countries. Furthermore, the rates of posttraumatic stress disorder (PTSD) cases reported after any disaster are much lower in developed countries than in countries in the developing world. ${ }^{4,5}$

According to the USGS, in the last 40 years there has been a 6 -fold increase in the number of earthquakes worldwide. During the same period, it was also detected that these disasters have been associated with increased incidence and prevalence of various psychiatric diseases amongst survivor groups, including acute stress disorder (ASD), PSTD, anxiety disorders, major depression, somatic complaints, and sleep disturbances.6,13 Although the consequences of any disaster may include a wide range of symptoms and psychopathologies; the majority of studies have documented that the most commonly present and most frequent psychopathology in the aftermath of natural disasters is PTSD. ${ }^{14,15}$ In this review article, we would like to highlight the considerable need to understand the characteristics and prevalence of PTSD symptomatology and the associated risk factors among survivors of recent major earthquakes worldwide, using data available in recent literature published over the last 20 years. This review also discusses other psychiatric complications associated with earthquakes, to enable readers to gain better understanding of the overall picture.

\section{Method}

A search for literature was conducted on major databases such as MEDLINE, PubMed, EMBASE, and PsycINFO, in neurology and psychiatry journals and many other medical journals, and in newspapers and other relevant articles describing the symptoms of mental health disorders in earthquake survivors. Terms used for electronic searches included PTSD, posttraumatic symptoms, anxiety, depression, major depressive disorder (MDD), prevalence, risk factors, earthquake, and natural disaster.

Detailed searches were undertaken of texts published from 1995 to 2016, to identify important mental health symptoms in the survivors of major earthquakes. No other inclusion or exclusion criteria were applied other than the relevance of articles (with the above-mentioned keywords) published between 1995 and 2016. A total of 
658 articles published in the last 20 years were identified and 77 of them that covered characteristics, prevalence and associated risk factors of PTSD symptomatology among survivors of recent major earthquakes were selected and their full-texts were used to prepare this mini-review. Relevant information was analyzed by all authors of this paper. The data were utilized for determining the relationship between earthquakes and posttraumatic stress symptoms, with consensus and agreement of all the authors involved.

\section{Results}

The most commonly studied posttraumatic stress symptoms and disorders among survivors of major earthquakes are described below.

Acute stress disorder (ASD) is a psychological condition in survivors of traumatic or life-threatening events or natural disasters. The symptoms may begin immediately after the event. The diagnosis of ASD was originally introduced in the Fourth Edition of the Diagnostic and Statistical Manual of Mental Disorders (DSM-IV) in 1994. ${ }^{16}$ Initially, it was recognized as a way of identifying victims at risk of developing PTSD. In 1998, Classen et al. provided evidence showing that survivors of traumatic events who met all of the symptom criteria for ASD were more likely to report PTSD symptoms 7 to 10 months later. ${ }^{17}$ On May 18th 2013, DSM-V was released by the American Psychiatric Association. ${ }^{18}$ In this edition, the idea that ASD is a precursor to PTSD had been abandoned, based on evidence-based research that has repeatedly shown mixed results. In a 2011 study, Bryant et al. concluded that ASD could not adequately identify the majority of people who would eventually develop PTSD. ${ }^{19}$

Christodoulou et al. assessed development of acute stress reaction among earthquake victims who sought help at a special psychosocial facility established after the 1999 Athens earthquake. ${ }^{7}$ They found that 85\% of the subjects who sought assistance met the ICD10 criteria for acute stress reaction and the remaining $15 \%$ had some acute stress symptoms. The study also concluded that there was a high prevalence of nonspecific symptoms of acute stress response in the acute posttraumatic phase. ${ }^{7}$

Posttraumatic stress disorder is described as pathological anxiety symptoms that last for more than one month after exposure to an actual or threatened death or a serious injury. This exposure can be a direct experience, witnessing a traumatic event, or may be the result of learning of a traumatic event that occurred to a close family member or a peer. It can occur in any person who experiences fear, helplessness, or horror following a natural disaster, such as an earthquake, that can involve threat of injury or death. As per DSM$5,{ }^{18}$ a diagnosis of PTSD requires symptoms from the following four groups to be present:

1) Persistent re-experiencing of the event: Images or thoughts, distressing dreams, illusions, hallucinations or dissociative flashback episodes, and intense physiological and psychological reactivity on exposure to internal or external cues that resemble an aspect of the event.

2) Avoidant symptoms: Avoidance of or efforts to avoid thoughts, feelings, or conversations related to the event. Avoidance of or efforts to avoid activities, people, and places that arouse recollections of the event.

3) Negative change in general responsiveness: Inability to recall an important aspect of the trauma, markedly diminished interest or participation in significant activities, feeling of detachment or estrangement from others, restricted range of affect, sense of foreshortened future.

4) Increased arousaland reactivity: Sleep disturbance, troubles concentrating, hypervigilance, exaggerated frightening or alarming response, irritability and outbursts of anger.

Anxiety is a universal human characteristic that can be defined as a particular mood state adapted to prepare for a possible, upcoming negative event. It has been found to be the second most prevalent symptom (after PTSD) among earthquake survivors. ${ }^{8,20-22}$ This state comprises both psychological and physiological symptoms. The psychological symptoms include uncontrollable worry, sleep disturbances, restlessness, hypervigilance, and difficulty concentrating. Patients with anxiety disorder self-report symptoms of constant worrying and fear responding to cues. ${ }^{8,20,22}$

Depression as per DSM-5 can be elicited as a depressed mood or a loss of pleasure in daily activities for more than two weeks. ${ }^{18}$ It is also associated with changes in sleep and appetite and loss of energy. Depression was among the major psychiatric symptoms reported along with PTSD and anxiety. ${ }^{9,10,21,23-27}$

Specific phobia is any kind of anxiety disorder that amounts to an unreasonable or irrational fear related to exposure to specific objects or situations. ${ }^{18}$ As a result, the person affected tends to actively avoid direct contact with these objects or situations and, in severe cases, any mention or depiction of them. In post-earthquake contexts, phobias are usually associated with loud sounds, thunder or thunderstorms, floods, deaths, and possible future earthquakes. 


\section{Discussion}

Posttraumatic stress disorder is the most commonly studied mental health issue among the survivors of natural disasters like earthquakes and it is probably the most common and debilitating too. ${ }^{14,15,28}$ In addition to PTSD, the depression and anxiety symptoms described above were also all commonly seen in some earthquake survivors. ${ }^{21}$ Although not particularly common, these were found to be pertinent in a study conducted after a massively destructive earthquake that hit Pakistan in $2008 .^{21}$ The results showed that around $63 \%$ of women had anxiety and 54\% had depressive symptoms. ${ }^{21}$

The lifetime prevalence of PTSD in the general population is estimated to be $7.8 \%$, with prevalence rates of $10.4 \%$ in females and $5.4 \%$ in males. ${ }^{20}$ Most of the studies of survivors of earthquakes investigated the prevalence of mental health disorders including PTSD and MDD. Other studies measured different risk factors causing mental health disorders and associations between PTSD and depressive symptoms and purpose in life, religious coping, and social support. ${ }^{11,29}$ Although there is a wide variation in PTSD prevalence rates reported in the literature, ranging from 11.7 to $86.7 \%,{ }^{21-23,28}$ they largely depend upon several contributing factors, including sociodemographic variables such as age, gender, low socioeconomic group, marital status, and educational background; and disaster-related variables such as close proximity to the epicenter, personal injuries, and death of loved ones. ${ }^{30-32}$ However, a small number of studies also identify pre-disaster and post-disaster risk factors that influence patient mental health, such as previous psychiatric illness, childhood abuse, lack of social, psychological, and financial support, or living in shelters with multiple relocations. ${ }^{33-35}$ In a 3-year case-control study, several independent risk factors for chronic PTSD were also identified, including witnessing someone being killed in the earthquake, having no regular income after the earthquake, receiving mental health support only once after the earthquake, and lower social support. ${ }^{36}$ Furthermore, it has also been found that early recognition of these risk factors and appropriate intervention can reduce the occurrence of PTSD. ${ }^{3}$

Several studies in the scientific literature suggest that females are at higher risk of developing anxiety, depression, and PTSD. ${ }^{11,24,37-39}$ Although, some studies have shown a significantly stronger likelihood of development of PTSD in females, being female has nevertheless not been proven to be an independent risk factor for PTSD. ${ }^{40,41}$ According to Naeem et al, the possibility of women thinking more about the disaster and having more recalls about the incident made females more prone to development of PTSD than males. ${ }^{42}$ Furthermore, these findings may be partly influenced by cultural factors. In many societies females are more dependent and have more emotional attachment to their families than males. ${ }^{21}$ It is imperative to provide prioritized psychosocial support to this group, as females are more likely to develop PTSD than males. ${ }^{43}$ Several factors such as lack of spousal support, separation from family members, living in tents, lack of socioeconomic autonomy due to cultural constraints, and difficulty accessing health facilities increase the risk of PTSD severalfold.21,32,44 Although very few studies have been conducted investigating female mental health and reproductive health after any natural disaster, the association has been well-established in recent years. ${ }^{45-47}$ Previous studies revealed that the presence of high levels of stress during pregnancy may be associated with poor birth outcomes after natural disaster. ${ }^{48,49}$ However, due to the large-scale land disruption and population displacement caused by earthquakes, they may lead to unavailability of and limited access to proper prenatal care, safe birthing services, and contraceptive methods. This also potentially increases the chances of birth defects and low birth weight pregnancies. ${ }^{50}$ Few studies have been conducted to assess the temporal association between PTSD and female reproductive health after earthquakes. One study demonstrated significant associations between PTSD and female reproductive health; while another study concluded that women with PTSD are a high-risk group for pregnancy complications. ${ }^{25,51,52}$

Moreover, one study revealed that the survivor's age was not significantly related to development of psychological symptoms, particularly PTSD. ${ }^{53}$ On the other hand, according to a study by Jia et al., the elderly population was also found to suffer considerable psychological impact and to be prone to development of mental health symptoms after having been in serious danger or having lost family members and having felt guilt based on restricted physical access. ${ }^{54}$ Disaster events, like earthquakes, can make children and adolescents more vulnerable because of their dependency on others. ${ }^{55}$ Many psychiatric and somatic symptoms were reported in children and young survivors in studies identified by Giannopoulou et al \& Bui et al. ${ }^{56,57}$ These include sleep disruption, nightmares, fears linked to the traumatic event, excessive clinging to caregivers, separation anxiety, loss of previously acquired skills, hyperactivity, irritability, difficulty in concentration, panic attacks, generalized anxiety disorder (GAD), depression, and substance abuse. In an epidemiological data collection study, Giannopoulou et al. reported prevalence rates of posttraumatic 
symptoms ranging from 21 to $70 \%$ in young survivors of earthquakes in Taiwan and Armenia. ${ }^{56}$ In a case control study, Blanc et al. compared the effectiveness of a specific psychosocial support and the prevalence of PTSD and depression in two groups of schoolchildren one year after the 2010 earthquake in Haiti. ${ }^{9}$ The study failed to report any significant difference in children who received psychosocial support compared to children who had not been monitored. However, the authors detected higher rates of PTSD and severe depression ( $68 \%$ and $40.9 \%$, respectively) than in the counterpart control group of children with psychosocial support (50\% and $20.5 \%) .{ }^{9}$ Similar to previous studies, ${ }^{57}$ this study also found a positive correlation between the intensity of peritraumatic distress and the severity of posttraumatic symptoms.

In a study conducted after the 2011 Wenchuan earthquake, lower socioeconomic status was found to be significantly related to development of psychological difficulties. Similarly, differences in living conditions were also factors that influenced emergence of symptoms. Those residing in temporary houses were more prone to damage and to subsequent development of PTSD symptoms as compared to those who resided in original permanent houses. ${ }^{58}$

Earthquake exposure is associated with psychological consequences including, but not limited to, development of persistent PTSD, even several months after the disaster. However, extensive research has not been carried out in this area to monitor and assess the resulting effects and symptoms in the survivors of an earthquake or other disasters. High prevalence rates of PTSD have been demonstrated years after the initial incident even in areas with good rehabilitation measures. ${ }^{24,28}$ In a Turkish study, in addition to PTSD, the prevalence of MDD, panic disorder, obsessivecompulsive disorder (OCD), GAD, social phobia, and specific phobias were shown to still be higher in the affected region three years after an earthquake. ${ }^{28}$

In a survey carried out 6 - 11 months after the disaster, among the survivors of the 2011 earthquake and tsunami in Japan, Yokoyama et al. identified several risk factors for post-earthquake psychiatric illnesses, including female sex, being a younger male, having health complaints, severe economic status, relocations, and lack of social networks. ${ }^{39}$ In contrast to this survey, as we have mentioned above, other surveys have shown that older individuals have a greater associated risk of mental health problems than younger individuals. ${ }^{55}$ It is also important to note that relocation after a disaster increases psychological distress, especially in females and in those who have experienced multiple relocations. ${ }^{26}$ Another finding of the Yokoyama study, which is consistent with previous studies, is the significant association between lack of social networks and severe psychiatric illness; as disasters eliminate significant number of supporters from victims' social networks through death. ${ }^{59-61}$

Very few studies have been conducted on PTSD in children and adolescents after earthquakes. There is a wide variation in PTSD prevalence rates reported by various studies, ranging from $4.5 \%$ to $95 \% .{ }^{54,62}$ One study estimated a prevalence rate of $17.5 \%$ in adolescent survivors from Wenchuan after 3 years. ${ }^{63}$ Another study reported a $35.7 \%$ prevalence rate of PTSD among children aged 9-17 years, 6-7 months after the earthquake. ${ }^{57}$ These prevalence rates point to the importance of an appropriate post-disaster mental health intervention program, which is needed to prevent development of PTSD in this age group. In adolescents, various risk factors for PTSD after disasters have been widely studied. It has been shown that girls are more likely to develop PTSD after earthquake exposure than boys. ${ }^{64-66}$ Other contributing risk factors for development of PTSD in adolescent survivors are the same as for adults, such as witnessing injury and death, loss of house and property, injury or death of family members, lack of social support after a natural disaster, and personal injury. ${ }^{64-67}$ These findings show that appropriate mental health interventions are needed to help adolescent survivors deal with PTSD after earthquakes.

Posttraumatic stress disorder symptoms have been widely studied and are an area of major interest after massive earthquakes in some countries. ${ }^{68-71}$ Although extensive data on PTSD after earthquakes are not available in the scientific literature, the findings from some relevant studies from different countries have been summarized in Table 1 .

The consequences of earthquake can sometimes be overwhelming and uncontrollable, even if all preventive measures are taken and sometimes even after low magnitude earthquakes. However, strong social support is one major coping skill mechanism that can be utilized to minimize mental health symptoms.

\section{Conclusion}

Based on a review of 77 studies from the literature published over the last two decades, we conclude that there is a wide variation in prevalence rates of PTSD among earthquake survivors, which largely depends upon several contributing factors. Females appear to be the most widely affected group and are at higher risk as compared to males, based on the available data. In terms of age, elderly populations and young children were found to suffer 
Table 1 - Selected studies of some major earthquakes and their findings related to PTSD.

\begin{tabular}{|c|c|c|c|c|c|}
\hline $\begin{array}{l}\text { Author and year } \\
\text { of publication }\end{array}$ & Country & Study design & Population & $\begin{array}{l}\text { Sample } \\
\text { size }\end{array}$ & Main findings \\
\hline Dai et al., $2016^{72}$ & China & $\begin{array}{l}\text { Meta-analysis } \\
\text { of } 46 \text { studies }\end{array}$ & & 76,101 & $\begin{array}{l}\text { Using a random effects model, the combined } \\
\text { incidence of PTSD after earthquakes was } 23.66 \% \text {. } \\
\text { The incidence of PTSD varied significantly across } \\
\text { studies in relation to the time of assessment, } \\
\text { gender, educational level, damage to one's house, } \\
\text { bereavement, bodily injury, and witnessing death. }\end{array}$ \\
\hline Liu et al., $2016^{73}$ & Tibet & $\begin{array}{l}\text { Cross- } \\
\text { sectional }\end{array}$ & $\begin{array}{l}\text { PTSD and its } \\
\text { predictors among } \\
4,072 \text { Tibetan } \\
\text { adolescents } 3 \\
\text { years after the } \\
\text { earthquake. }\end{array}$ & 4,072 & $\begin{array}{l}\text { PTSD prevalence was } 17.8 \% \text {. Factors predictive of } \\
\text { PTSD were age } 14 \text { or over, being a senior student, } \\
\text { monitor, buried or injured, death or amputation } \\
\text { of family member, more severe property loss, } \\
\text { witnessing death, and having negative coping skills }\end{array}$ \\
\hline Rahill et al., $2015^{74}$ & Haiti & $\begin{array}{l}\text { Cross- } \\
\text { sectional }\end{array}$ & $\begin{array}{l}2 \text { groups of } 16 \\
\text { women }\end{array}$ & 16 & $\begin{array}{l}\text { This study included a small sample of women in } \\
\text { Haiti who had suffered sexual violence perpetrated } \\
\text { by non-intimate partners/strangers (NPSV). } \\
\text { The psychological effects of NPSV included self- } \\
\text { reported PTSD criteria, including physiological, } \\
\text { neurological and psychological symptoms, } \\
\text { avoidance, arousal, cognitive and mood changes, } \\
\text { as well as significant distress/impairment in } \\
\text { various areas of functioning. }\end{array}$ \\
\hline $\begin{array}{l}\text { Bianchini et al., } \\
2015^{75}\end{array}$ & $\begin{array}{l}\text { L'Aquila } \\
\text { (Italy) }\end{array}$ & $\begin{array}{l}\text { Cross- } \\
\text { sectional }\end{array}$ & $\begin{array}{l}\text { College students } \\
\text { two years after } \\
\text { the } 2009 \text { L'Aquila } \\
\text { earthquake, } \\
\text { assessing coping } \\
\text { strategies including } \\
\text { posttraumatic } \\
\text { growth and } \\
\text { substance abuse }\end{array}$ & 411 & $\begin{array}{l}\text { The posttraumatic growth (PTG) mean score } \\
\text { was } 35.23 \text {, underlining low positive coping } \\
\text { strategies among student community. } 43.8 \% \\
\text { of students reported an increase in alcohol use, } \\
7.8 \% \text { in cannabis and } 15.8 \% \text { in nicotine use in } \\
\text { the post-earthquake period. However, } 12.5 \% \text { of } \\
\text { the students reported a decrease in alcohol use } \\
\text { after the earthquake and } 17.3 \% \text { reported a PTG, } \\
\text { showing positive behaviors and attitudes. }\end{array}$ \\
\hline Cofini et al., $2015^{76}$ & $\begin{array}{l}\text { L'Aquila } \\
\text { (Italy) }\end{array}$ & $\begin{array}{l}\text { Cross- } \\
\text { sectional }\end{array}$ & $\begin{array}{l}\text { Sample of } 281 \\
\text { people aged }>18 \\
\text { years and living } \\
\text { in temporary } \\
\text { housing after the } \\
\text { earthquake }\end{array}$ & 281 & $\begin{array}{l}\text { People living in temporary housing after the } \\
\text { earthquake experienced high rates of PTSD. } \\
\text { Prevalence of PTSD was } 43 \% \text {. Women and the } \\
\text { non-employed were more vulnerable to PTSD, } \\
\text { while, age and level of education were not } \\
\text { associated with PTSD. People with PTSD exhibited } \\
\text { denial, venting, behavioral disengagement and } \\
\text { self-blame as coping strategies. }\end{array}$ \\
\hline Shrestha, $2015^{77}$ & Nepal & $\begin{array}{l}\text { Cross- } \\
\text { sectional }\end{array}$ & $\begin{array}{l}\text { Medical } \\
\text { professionals } \\
\text { at Manmohan } \\
\text { Memorial } \\
\text { Teaching Hospital } \\
\text { (Kathmandu) }\end{array}$ & 64 & $\begin{array}{l}\text { Prevalence rates of PTSD were } 21.9 \% \text { and } 17.1 \% \\
\text { (using different cutoff score and diagnostic } \\
\text { criteria) Females }>\text { males. No significant difference } \\
\text { was observed according to age, marital status, } \\
\text { profession, previous disaster experience, or tragic } \\
\text { events with relatives. }\end{array}$ \\
\hline $\begin{array}{l}\text { Cénat \& Derivois, } \\
2014^{24}\end{array}$ & France & $\begin{array}{l}\text { Cross- } \\
\text { sectional study }\end{array}$ & $\begin{array}{l}30 \text { months after the } \\
2010 \text { earthquake } \\
\text { disaster in Haiti, } \\
1,355 \text { participants, } \\
\text { adults, aged } 18 \text { or } \\
\text { over with no prior } \\
\text { psychiatric illness, } \\
\text { were enrolled } \\
\text { on this study. } \\
\text { All assessment } \\
\text { variables were } \\
\text { measured using a } \\
\text { self-administered } \\
\text { questionnaire. }\end{array}$ & 1,355 & $\begin{array}{l}\text { The results of this French study showed prevalence } \\
\text { rates of } 36.75 \% \text { of PTSD symptoms and } 25.98 \% \\
\text { of depression } 2.5 \text { years after the disastrous } \\
\text { earthquake affecting the capital and other cities } \\
\text { across the country. Female gender, being young } \\
\text { or a student, elderly, and unemployment were } \\
\text { found to be risk factors for PTSD and Depression. } \\
\text { Participants with a low level of education } \\
\text { were shown to have the highest prevalence of } \\
\text { depression. There were also significant links } \\
\text { between peritraumatic distress and subsequent } \\
\text { development of PTSD and depression. }\end{array}$ \\
\hline $\begin{array}{l}\text { Yokoyama et al., } \\
2014^{39}\end{array}$ & Japan & $\begin{array}{l}\text { Cross- } \\
\text { sectional } \\
\text { survey }\end{array}$ & $\begin{array}{l}\text { The survey was } \\
\text { carried out in } 3 \\
\text { municipalities of } \\
\text { the northern part } \\
\text { Honshu, Japan. } \\
10,025 \text { participants } \\
\text { aged } 18 \text { or older } \\
\text { were included and } \\
\text { assessed with a } \\
\text { health survey and a } \\
\text { questionnaire. }\end{array}$ & 10,025 & $\begin{array}{l}\text { In this Japanese study, } 42.6 \% \text { of survivors were } \\
\text { determined to have MMHPs or SMHPs. In addition, } \\
\text { many risk factors associated with mental health } \\
\text { problems were determined: Female gender, } \\
\text { younger age group, and frequency of relocation } \\
\text { were of greatest significance. The study also } \\
\text { emphasized the creation of permanent jobs and } \\
\text { measures to attract firms to invest and establish } \\
\text { plants in devastated areas as support for victims } \\
\text { seeking new employment. }\end{array}$ \\
\hline
\end{tabular}




\begin{tabular}{|c|c|c|c|c|c|}
\hline $\begin{array}{l}\text { Author and year } \\
\text { of publication }\end{array}$ & Country & Study design & Population & $\begin{array}{l}\text { Sample } \\
\text { size }\end{array}$ & Main findings \\
\hline Feder et al., $2013^{11}$ & $\begin{array}{l}\text { United } \\
\text { States }\end{array}$ & $\begin{array}{l}\text { Cross- } \\
\text { sectional } \\
\text { survey }\end{array}$ & $\begin{array}{l}200 \text { adult } \\
\text { earthquake } \\
\text { survivors from } \\
\text { affected areas of } \\
\text { North-western } \\
\text { Pakistan were } \\
\text { recruited in this } \\
\text { study and all } \\
\text { variables of interest } \\
\text { were completed by } \\
\text { a self-administered } \\
\text { questionnaire. }\end{array}$ & 200 & $\begin{array}{l}\text { This study conducted by the Mount Sinai School } \\
\text { of Medicine three years after the } 2005 \text { earthquake } \\
\text { in Pakistan concluded that } 64.6 \% \text { of participants } \\
\text { met criteria of probable PTSD three years after the } \\
\text { deadly disaster. Female gender, lower education, } \\
\text { loss of close family members, and negative } \\
\text { religious coping were found to be associated with } \\
\text { higher posttraumatic symptom levels. On the } \\
\text { other hand, higher purpose in life was found to be } \\
\text { associated with lower symptom levels and higher } \\
\text { self-reported positive emotions. }\end{array}$ \\
\hline Anwar et al., $2013^{21}$ & $\begin{array}{l}\text { Australia, } \\
\text { WHO }\end{array}$ & $\begin{array}{l}\text { Cross- } \\
\text { sectional } \\
\text { survey }\end{array}$ & $\begin{array}{l}\text { Women aged } 15 \\
\text { to } 49 \text { years and } \\
\text { married at the time } \\
\text { of survey, and who } \\
\text { experienced and } \\
\text { lived through the } \\
\text { earthquake }\end{array}$ & 425 & $\begin{array}{l}\text { This WHO study carried by the University of } \\
\text { Sydney reported multiple sociodemographic and } \\
\text { reproductive health factors as predictors of PTSD in } \\
\text { women after the } 2005 \text { earthquake in Pakistan. In } \\
\text { the conservative sociocultural context of Pakistan, } \\
\text { social support was found to be one of the most } \\
\text { important predictors of PTSD. Use of temporary } \\
\text { accommodation, previous complications with } \\
\text { pregnancies, abnormal vaginal discharge, use of } \\
\text { injectable contraceptives, knowledge about STDs, } \\
\text { and difficult access to health facilities were other } \\
\text { significant risk factors for PTSD. }\end{array}$ \\
\hline Zhou et al., $2013^{38}$ & China & $\begin{array}{l}\text { Cross- } \\
\text { sectional study }\end{array}$ & $\begin{array}{l}\text { Age and Sex } \\
\text { matched random } \\
\text { sample of } 10 \% \text { of } \\
\text { the respondents } \\
\text { was chosen. Data } \\
\text { was collected } 6 \\
\text { months after the } \\
\text { disaster. }\end{array}$ & 14,207 & $\begin{array}{l}\text { The study reported prevalence of } 15.57 \% \\
\text { of PTSD among survivors of earthquake. It } \\
\text { identified several risk factors for PTSD: older age, } \\
\text { female gender, living alone, being buried in the } \\
\text { earthquake, injured in the earthquake, operated } \\
\text { on after the earthquake, witnessing someone get } \\
\text { injured in the earthquake, witnessing someone } \\
\text { get buried in the earthquake, witnessing someone } \\
\text { die in the earthquake. The study was unable } \\
\text { to draw any relationship between the level of } \\
\text { education and PTSD. }\end{array}$ \\
\hline$\square$ nder et al., $2006^{28}$ & Turkey & $\begin{array}{l}\text { Cross- } \\
\text { sectional } \\
\text { survey }\end{array}$ & $\begin{array}{l}36 \text { months after } \\
\text { the } 1999 \text { Marmara } \\
\text { earthquake in } \\
\text { Turkey, } 683 \\
\text { participants aged } \\
18 \text { or over were } \\
\text { randomly selected } \\
\text { from seven } \\
\text { municipalities of } \\
\text { Kocaeli City to be } \\
\text { assessed by a face } \\
\text { to face household } \\
\text { interview survey } \\
\text { called Marmara } \\
\text { Earthquake Survey } \\
\text { (MES). }\end{array}$ & 683 & $\begin{array}{l}\text { This study showed that the } 3-y e a r \text { period } \\
\text { prevalence rates of PTSD and MDD were } 19.2 \% \\
\text { and } 18.7 \% \text { respectively while the current } \\
\text { point prevalence rates were } 11.7 \% \text { and } 10.5 \% \\
\text { respectively. The prevalence of panic disorder, } \\
\text { OCD, GAD, social phobias, and specific phobias } \\
\text { were also found to be at least two times greater } \\
\text { than the pre-earthquake national prevalence rates } \\
\text { of these disorders. The study also found that } \\
\text { psychological distress was significantly greater in } \\
\text { the comorbid PTSD and MDD group than in the } \\
\text { group with PTSD alone. }\end{array}$ \\
\hline $\begin{array}{l}\text { Sharan et al., } \\
1996^{55}\end{array}$ & India & $\begin{array}{l}\text { Cross- } \\
\text { sectional } \\
\text { survey }\end{array}$ & $\begin{array}{l}56 \text { participants } \\
\text { aged } 14 \text { or older } \\
\text { from } 23 \text { households } \\
\text { in three villages in } \\
\text { western India were } \\
\text { interviewed. }\end{array}$ & 56 & $\begin{array}{l}\text { The study reported a rate of } 59 \% \text { of psychiatric } \\
\text { disorder post-earthquake in a rural community in } \\
\text { India. Of these, PTSD ( } 23 \% \text { ) and major depression } \\
\text { ( } 21 \%) \text { were the most frequent disorders. } \\
\text { Destruction of house and possessions and stress of } \\
\text { losses and relocation were found to have acted as } \\
\text { life-threatening risk factors. }\end{array}$ \\
\hline
\end{tabular}

$\mathrm{PTSD}=$ posttraumatic stress disorder; $\mathrm{MDD}=$ major depressive disorder; $\mathrm{OCD}=$ obsessive-compulsive disorder; $\mathrm{GAD}=$ generalized anxiety disorder; $\mathrm{MMHP}=$ moderate mental health problem; SMHP = severe mental health problem.

considerable psychosocial impact. Multiple risk factors come into play in development of psychological symptoms. While it is sometimes argued that the psychological symptoms that result after major natural disasters such as earthquakes are time-limited and may fade away or may completely resolve on their own if left untreated, several studies have shown high prevalence rates even years after the incident. Nevertheless, more research is needed in this area to study risk factors involved in provoking, and responsible for, increased prevalence of these psychological symptoms, particularly PTSD. These disasters can be catastrophic and leave a permanent tragic impact, unconsciously impacting 
people's overall mental health. From this literature review, we conclude that early identification of symptoms through assessment of peritraumatic distress by mental health professional a few hours or a few days after the event can detect risk factors. With early recognition, those at risk for development of psychological symptoms, in particular of PTSD, can be targeted for intervention. Increased psychological and social support, support groups, and creating employment opportunities for affected people can play a major role in reducing symptoms and preventing the development not only of PTSD but also of other major psychiatric comorbidities. Early identification of symptoms, early intervention, and monitoring response to treatment are some of the long-term preventive measures that can be utilized to increase the speed of recovery and ensure mental wellbeing.

\section{Disclosure}

No conflicts of interest declared concerning the publication of this article.

\section{References}

1. USGS. Earthquake facts [Internet]. [cited 2015 Dec 16]. Available from https://earthquake.usgs.gov/learn/facts.php

2. Wu Z, Xu J, He L. Psychological consequences and associated risk factors among adult survivors of the 2008 Wenchuan earthquake. BMC Psychiatry. 2014;14:126.

3. Tural U, Coşkun B, Onder E, Corapçioğlu A, Yildiz M, Kesepara C, et al. Psychological consequences of the 1999 earthquake in Turkey. J Trauma Stress. 2004;17:451-9.

4. Kuwabara H, Shioiri T, Toyabe S, Kawamura T, Koizumi M, ItoSawamura M, et al. Factors impacting on psychological distress and recovery after the 2004 Niigata-Chuetsu earthquake, Japan: community-based study. Psychiatry Clin Neurosci 2008;62:503-7.

5. Naeem F, Ayub M, Masood K, Gul H, Khalid M, Farrukh A, et al. Prevalence and psychosocial risk factors of PTSD: 18 months after Kashmir earthquake in Pakistan. J Affect Disord. 2011;130:268-74.

6. Karanci AN, Rustemly A. Psychological consequences of the 1992 Erzincan (Turkey) earthquake. Disasters. 1995;19:8-18.

7. Christodoulou GN, Paparrigopoulos TJ, Soldatos CR. Acute stress reaction among victims of the 1999 Athens earthquake: help seekers' profile. World Psychiatry. 2003;2:50-3.

8. Long J, Huang X, Liao $Y, \mathrm{Hu} \mathrm{X,} \mathrm{Hu} \mathrm{J,} \mathrm{Lui} \mathrm{S,} \mathrm{et} \mathrm{al.} \mathrm{Prediction} \mathrm{of}$ post-earthquake depressive and anxiety symptoms: a longitudinal resting-state fMRI study. Sci Rep. 2014;4:6423.

9. Blanc J, Bui E, Mouchenik Y, Derivois D, Birmes P. Prevalence of post-traumatic stress disorder and depression in two groups of children one year after the January 2010 earthquake in Haiti. J Affect Disord. 2014;172:121-6.

10. Goenjian AK, Roussos A, Steinberg AM, Sotiropoulou C, Walling $D$, Kakaki M, et al. Longitudinal study of PTSD, depression, and quality of life among adolescents after the Parnitha earthquake. J Affect Disord. 2011;33:509-15.

11. Feder A, Ahmad S, Lee EJ, Morgan JE, Singh R, Smith BW, et al. Coping and PTSD symptoms in Pakistani earthquake survivors: purpose in life, religious coping and social support. J Affect Disord. 2013;147:156-63.

12. Norenzayan A, Lee A. It was meant to happen: explaining cultural variations in fate attributions. J Pers Soc Psychol. 2010;98:702-20.

13. Roberts $\mathrm{YH}$, Mitchell MJ, Witman M, Taffaro C. Mental health symptoms in youth affected by Hurricane Katrina. Prof PsycholRes Pr. 2010;41:10-8.
14. Neria Y, Nandi A, Galea S. Post-traumatic stress disorder following disasters: a systematic review. Psychol Med. 2008;38:467-80.

15. North CS, Nixon SJ, Shariat S, Mallonee S, McMillen JC, Spitznagel $\mathrm{EL}$, et al. Psychiatric disorders among survivors of the Oklahoma City bombing. JAMA. 1999;282:755-62

16. American Psychiatric Association. Diagnostic and Statistica Manual of Mental Disorders, Fourth Edition (DSM-IV). Arlington: American Psychiatric Publishing; 1994.

17. Classen C, Koopman C, Hales R, Spiegel D. Acute stress disorder as a predictor of posttraumatic stress symptoms. Am J Psychiatry. 1998; $155: 620-4$.

18. American Psychiatric Association. Diagnostic and Statistical Manual of Mental Disorders, Fifth Edition (DSM-5). Arlington: American Psychiatric Publishing; 2013.

19. Bryant RA. Acute stress disorder as a predictor of posttraumatic stress disorder: a systematic review. J Clin Psychiatry. 2011;233-9.

20. Breslau N. Epidemiologic studies of trauma, posttraumatic stress disorder, and other psychiatric disorder. Can. J. Psychiatry. 2002; 47:923-29.

21. Anwar J, Mpofu E, Matthews LR, Shadoul AF, Brock KE. Reproductive health and access to healthcare facilities: risk factors for depression and anxiety in women with an earthquake experience. BMC Public Health. 2011;11:523.

22. Goenjian, A.K., Steinberg, A.M., Najarian, L.M., Fairbanks, L.A., Tashjian, M., Pynoos, R.S. Prospective study of posttraumatic stress, anxiety, and depressive reactions after earthquake and political violence. Am J Psychiatry. 2000;157:911-16.

23. Basoglu, M., Kilic, C., Salcioglu, E., Livanou, M. Prevalence of posttraumatic stress disorder and comorbid depression in earthquake survivors in Turkey: an epidemiological study. J Trauma Stress. 2004;17:133-41.

24. Cénat JM, Derivois D. Assessment of prevalence and determinants of posttraumatic stress disorder and depression symptoms in adult survivors of earthquake in Haiti after 30 months. J Affect Disord. 2014;159:111-7.

25. Clum GA, Calhoun KS, Kimerling R. Associations among symptoms of depression and posttraumatic stress disorder and self-reported health in sexually assaulted women. J Nerv Ment Dis. 2000;188:671-8.

26. Inaba $A$, Thoits $P A$, Ueno $K$, Gove WR, Evenson $R J$, et al Depression in the United States and Japan: gender, marital status, and SES patterns. Soc Sci Med. 2005;61: 2280-92.

27. Sharan P, Chaudhary G, Kavathekar SA, Saxena S. Preliminary report of psychiatric disorders in survivors of a severe earthquake. Am J Psychiatry. 1996;153:556-8.

28. Onder E, Tural U, Aker T, Kiliç C, Erdoğan S. Prevalence of psychiatric disorders three years after the 1999 earthquake in Turkey: Marmara Earthquake Survey (MES). Soc Psychiatry Psychiatr Epidemiol. 2006;41:868-74.

29. Wu Z, Xu J, He L. Psychological consequences and associated risk factors among adult survivors of the 2008 Wenchuan earthquake. BMC Psychiatry. 2014;14:126.

30. Brewin CR, Andrews B, Valentine JD. Meta-analysis of risk factors for posttraumatic stress disorder in trauma-exposed adults. Journal of Consulting and Clinical Psychology. 2000;68: 748-66.

31. Breslau N, Kessler RC, Chilcoat HD, Schultz LR, Davis GC, et al. Trauma and post-traumatic stress disorder in the community: The 1996 Detroit Area Survey of Trauma. American Journal of Psychiatry. 1998;55: 626-32.

32. Kun P, Han S, Chen X, Yao L. Prevalence and risk factors for posttraumatic stress disorder: a cross-sectional study among survivors of the Wenchuan 2008 earthquake in China. Depress and Anxiety. 2009;26:1134-40.

33. Agustini EN, Asniar I, Matsuo $H$. The prevalence of long-term posttraumatic stress symptoms among adolescents after the tsunami in Aceh. Journal of Psychiatric and Mental Health Nursing. 2011;18:543-49.

34. Ma X, Liu X, Hu X, Qiu C, Wang Y, Huang $Y$, et al. Risk indicators for posttraumatic stress disorder in adolescents exposed to the 5.12 Wenchuan earthquake in China. Psychiatry Research. 2011;189:385-91.

35. Wang L, Zhang Y, Wang W, Shi Z, Shen J, Li M, et al. Symptoms of posttraumatic stress disorder among adult survivors three months after the Sichuan earthquake in China. Journal of Traumatic Stress. 2009; 22:444-50.

36. Cheng $Y$, Wang F, Wen J, Shi Y. Risk factors of post-traumatic stress disorder (PTSD) after Wenchuan earthquake: a case control study. PLoS One. 2014; 9: e96644. 
37. Zhou X, Kang L, Sun $X$, Song $H$, Mao W, Huang $X$, et al. Risk factors of mental illness among adult survivors after the Wenchuan earthquake. Soc Psychiatry Psychiatr Epidemiol. 2013;48:907-15.

38. Zhou $X$, Kang $L$, Sun $X$, Song $H$, Mao W, Huang $X$, Zhang $Y, L i$ J. Prevalence and risk factors of post-traumatic stress disorder among adult survivors six months after the Wenchuan earthquake. Compr Psychiatry. 2013;54:493-99.

39. Yokoyama $Y$, Otsuka K, Kawakami N, Kobayashi S, Ogawa A, Tannno $\mathrm{K}$, et al. Mental health and related factors after the Great East Japan earthquake and tsunami. PLoS One. 2014; 24;9: e102497.

40. Cheng $Y$, Wang F, Wen J, Shi Y. Risk factors of post-traumatic stress disorder (PTSD) after Wenchuan earthquake: a case control study. PLoS One. 2014;9:e96644.

41. Fu $Y$, Chen $Y$, Wang J, Tang $X, \mathrm{He} J$, Jiao $M$, et al. Analysis of prevalence of PTSD and its influencing factors among college students after the Wenchuan earthquake. Child Adolesc Psychiatry Ment Health. 2013;7:1.

42. Naeem F, Ayub M, Masood K, Gul H, Khalid M, Farrukh A, et al. Prevalence and psychosocial risk factors of PTSD: 18 months after Kashmir earthquake in Pakistan. J Affect Disord. 2011;130:268-74.

43. Punamaki RL, Komproe IH, Qouta S, Elmasri M, de Jong JT. The role of peritraumatic dissociation and gender in the association between trauma and mental health in a community sample. Am J Psychiatry. 2005;162:545-51.

44. Patel V, Kirkwood BR, Pednekar S, Weiss H, Mabey D. Risk factors for common mental disorders in women: Population-based longitudinal study. Br J Psychiatry. 2006;189:547-55.

45. Engelhard IM, van den Hout $M$, Arntz A. Posttraumatic stress disorder after pregnancy loss. Gen Hosp Psychiatry. 2001;23:62-6.

46. Forray A, Mayes LC, Magriples U, Epperson CN. Prevalence of posttraumatic stress disorder in pregnant women with prior pregnancy complications. J Matern Fetal Neonatal Med. 2009;22:522-7.

47. World Health Organization. Mental health aspects of women's reproductive health: A global review of the literature. Geneva: WHO Press; 2009.

48. Buekens $P$, Xiong $X$, Harville E. Hurricanes and pregnancy. Birth. 2006;33:91-3.

49. Callaghan WM, Rasmussen SA, Jamieson DJ, Ventura SJ, Farr SL, Sutton PD, et al. Health concerns of women and infants in times of natural disasters: Lessons learned from Hurricane Katrina. Matern Child Health J. 2007;11:307-11.

50. Otsea K. Prioritizing reproductive health for refugees. Initiat Reprod Health Policy. 1999;3:1-3

51. Patel V, Kirkwood BR, Pednekar S, Pereira B, Barros P, Fernandes J, Datta J, Pai R, Weiss H, Mabey D. Gender disadvantage and reproductive health risk factors for common mental disorders in women: A community survey in India. Arch Gen Psychiatry. 2006;63:404-13.

52. Seng JS, Oakley DJ, Sampselle CM, Killion C, Graham-Bermann S, Liberzon I. Posttraumatic stress disorder and pregnancy complications. Obstet Gynecol. 2001:97:17-22.

53. Kun $P$, Chen X, Han S, Gong X, Chen M, Zhang W, et al. Prevalence of post-traumatic stress disorder in Sichuan Province, China after the 2008 Wenchuan earthquake. Public Health, 2009;123:70307.

54. Jia Z, Tian W, Liu W, Cao Y, Yan J, Shun Z. Are the elderly more vulnerable to psychological impact of natural disaster? A population-based survey of adult survivors of the 2008 Sichuan earthquake. BMC Public Health. 2010;10:172.

55. Ursano R, Norwood AE, editors. Trauma and disaster responses and management. Washington, DC: American Psychiatric Publishing; 2003. p. 63-90.

56. Giannopoulou I, Strouthos M, Smith P, Dikaiakou A, Galanopoulou $V$, Yule W. Post-traumatic stress reactions of children and adolescents exposed to the Athens 1999 earthquake. Eur Psychiatry. 2006;21:160-6.

57. Bui E, Brunet A, Allenou C, Camassel C, Raynaud JP, Claudet I, et al. Peritraumatic reactions and post-traumatic stress symptoms in school-aged children victims of road traffic accident. Gen Hosp Psychiatry. 2010;32:330-3.

58. Yuan KC, Ruo Yao Z, Zhen Yu S, Xu Dong Z, Jian Zhong Y, Edwards $J G$, et al. Prevalence and predictors of stress disorders following two earthquakes. Int J Soc Psychiatry. 2013;59:525-30.

59. Norris FH, Friedman MJ, Watson PJ, Byrne CM, Diaz E, et al. 60,000 disaster victims speak: Part I. An empirical review of the empirical literature, 1981-2001. Psychiatry. 2002;65;207-39.
60. OyamaM, Nakamura K, Suda Y, Someya T. Social network disruption as a major factor associated with psychological distress 3 years after the 2004 Niigata-Chuetsu earthquake in Japan. Environmental health and preventive medicine. 2012;17:118-23.

61. Jia Z, Tian W, Liu W, Cao Y, Yan J, et al. Are the elderly more vulnerable to psychological impact of natural disaster? A population-based survey of adult survivors of the 2008 Sichuan earthquake. BMC Public Health. 2010;10:172.

62. Altindaga AT, Ozenb S, Sir A. One-year follow-up study of posttraumatic stress disorder among earthquake survivors in Turkey. Compr Psychiatry. 2005;46:328-33.

63. Tian $Y$, Wong TK, Li J, Jiang $X$. Posttraumatic stress disorder and its risk factors among adolescent survivors three years after an 8.0 magnitude earthquake in China. BMC Public Health. 2014;14:1073.

64. Roussos A, Goenjian AK, Steinberg AM, Sotiropoulou C, Kakaki M, Kabakos C, et al. Posttraumatic stress and depressive reactions among children and adolescents after the 1999 earthquake in Ano Liosia, Greece. Am J Psychiatry. 2005;162:530-7.

65. Goenjian AK, Walling D, Steinberg AM, Karayan I, Najarian LM, Pynoos R: A prospective study of posttraumatic stress and depressive reactions among treated and untreated adolescents 5 years after a catastrophic disaster. Am J Psychiatry. 2005; 162:2302-8.

66. Goenjian AK, Pynoos RS, Steinberg AM, Najarian LM, Asarnow JR, Karayan I, et al. Psychiatric comorbidity in children after the 1988 earthquake in Armenia. J Am Acad Child Adolesc Psychiatry. 1995;34:1174-84.

67. Liu KZ, Liang XM, Guo LT, Li Y, Li XR, Xin B, et al. The acute stress disorder in the paediatric surgical children and adolescents injured in the Wenchuan earthquake of China. Steess Health. 2010;1:75-81.

68. Priebe S, Marchi F, Bini L, et al. Mental disorders, psychological symptoms and quality of life 8 years after an earthquake: findings from a community sample in Italy. Soc Psychiatry Psychiatr Epidemiol. 2011;46:615-21.

69. Wang B, Ni C, Chen J, Liu X, Wang A, Shao Z, et al. Posttraumatic stress disorder 1 month after 2008 earthquake in China: Wenchuan earthquake survey. Psychiatry Res. 2011;187:392-6.

70. Goenjian AK, Roussos A, Steinberg AM, Sotiropoulou C, Walling $D$, Kakaki M, et al. Longitudinal study of PTSD, depression, and quality of life among adolescents after the Parnitha earthquake. J Affect Disord. 2011;33:509-15.

71. Anwar J, Mpofu E, Matthews LR, Brock KE. Risk factors of posttraumatic stress disorder after an earthquake disaster. J Nerv Ment Dis. 2013;201:1045-52.

72. Dai W, Chen L, Lai Z, Li Y, Wang J, Liu A. The incidence of posttraumatic stress disorder among survivors after earthquakes: a systematic review and meta-analysis. BMC Psychiatry. 2016;16:188.

73. Liu D, Fu L, Jing Z, Chen C. Post-traumatic stress disorder and it's predictors among Tibetan adolescents 3 years after the high-altitude earthquake in China. Arch Psychiatr Nursing. 2016:30:593-9.

74. Rahill GJ, Joshi M, Lescano C, Holbert D. Symptoms of PTSD in a sample of female victims of sexual violence in post-earthquake Haiti. J Affect Disord. 2015;173:232-8.

75. Bianchini V, Roncone R, Giusti L, Casacchia M, Cifone MG, Pollice R. PTSD growth and substance abuse among a college student community: coping strategies after 2009 L'aquila Earthquake. Clin Pract Epidemiol Ment Health. 2015;11:140-3.

76. Cofini V, Carbonelli A, Cecilia MR, Binkin N, di Orio F. Post traumatic stress disorder and coping in a sample of adult survivors of the Italian earthquake. Psychiatry Res. 2015;229:353-8.

77. Shrestha R. Post-traumatic stress disorder among medical personnel after Nepal earthquake, 2015. J Nepal Health Res Counc. 2015;13:144-8.

\section{Correspondence:}

Sajid S. Suriya

California Institute of Neurosciences (CIN)

2100 Lynn Road, Suite 120

Thousand Oaks, CA 91306

Tel. : +1 (805) 428-9688

Fax: +1 (805) 617-1743

Email: sajid.suriya@gmail.com 